\section{Psikolojik Güçlendirme Algısının Örgütsel Özdeşleşme Üzerindeki Etkisinde Kariyer Memnuniyetinin Aracılık Rolü}

\section{Beyza Erer}

Öz: Bu araştırmada, psikolojik güçlendirme algısının örgütsel özdeşleşme üzerindeki etkisi ve bu etkide kariyer memnuniyetinin aracı role sahip olup olmadığının belirlenmesi amaçlanmıştır. Bu amacın gerçekleştirilmesine yönelik bir model geliştirilmiş ve modelin test edilebilmesi için Konya ilinde hukuk bürolarında çalışan 262 avukattan anket tekniği ile veriler toplanmıştır. Elde edilen veriler, betimsel istatistikler, doğrulayıcı faktör analizi, korelasyon analizi ve yapısal eşitlik modeli ile değerlendirilmiştir. Korelasyon analizi sonucunda psikolojik güçlendirme algısı, örgütsel özdeşleşme ve kariyer memnuniyeti değişkenleri arasında pozitif yönlü ve anlamlı düzeyde ilişki tespit edilmiştir. Hipotezlerin test edilmesine yönelik oluşturulan yapısal eşitlik modelinde, psikolojik güçlendirme algısının hem örgütsel özdeşleşme hem de kariyer memnuniyeti üzerine etkisinin pozitif yönde ve anlamlı olduğu belirlenmiştir. Ayrıca kariyer memnuniyetinin örgütsel özdeşleşmeyi olumlu yönde etkilediği sonucuna ulaşılmıştır. Son olarak ise psikolojik güçlendirme algısının, örgütsel özdeşleşme üzerine etkisinde kariyer memnuniyetinin kısmi aracı rolünün olduğu tespit edilmiştir.

\section{The Mediating Role of Career Satisfaction in the Effect of Psychological Empowerment Perception on Organizational Identification}

Abstract: In this study, it is aimed to determine the effect of psychological empowerment perception on organizational identification and whether career satisfaction has a mediating role in this effect. A model for the realization of this goal was developed and in order to test the model, data were collected using a questionnaire technique from 262 lawyers working in law offices in Konya. The data obtained were evaluated using descriptive statistics, confirmatory factor analysis, correlation analysis, and structural equation model. As a result of the correlation analysis, positive and significant relationships were found among the variables of psychological empowerment perception, organizational identification, and career satisfaction. In the structural equation model performed to test the hypotheses, it was determined that the effect of psychological empowerment perception on both organizational identification and career satisfaction was found to be positive and significant. In addition, it has been concluded that career satisfaction positively affects organizational identification. Finally, it has been determined that career satisfaction has a partial mediating role in the effect of psychological empowerment perception on organizational identification.
Anahtar Sözcükler: Personel güçlendirme, Yapısal güçlendirme, Psikolojik Güçlendirme, Örgütsel Özdeşleşme, Kariyer Memnuniyeti

JEL: M10, M19

$\begin{array}{ll}\text { Geliş } & : \text { 11 Ocak } 2021 \\ \text { Düzeltme } & : 01 \text { Mart } 2021 \\ \text { Kabul } & : 08 \text { Nisan 2021 } \\ & \\ \text { Tür } & \text { : Araştırma }\end{array}$

Keywords: Empowerment, Structural Empowerment, Psychological Empowerment, Organizational Identification, Career Satisfaction

JEL: M10, M19

a Lecturer, PhD., Selcuk University, Social Sciences Vocational School, Department of Business Administration, Konya, Turkiye, beyzaerer@selcuk.edu.tr (ORCID ID: 0000-0003-0083-7102) 


\section{Giriş}

Değişimin ve gelişimin sürekli hale geldiği günümüz iş yaşamında, işletmelerin rekabetçi piyasa koşullarında yaşamlarını sürdürerek verimliliklerini artırabilmeleri ve rekabet üstünlüğü sağlayabilmeleri mevcut insan kaynağının başarısına bağlıdır. Bu durumu farkında olan yöneticiler, örgütün gelişmesine, amaçlarına ve örgütsel çıktıların başarılmasına katkıda bulunan pozitif örgütsel davranışlara önem vermeye başlamışlar ve çalışanların verimliliğini artıracak çağdaş insan kaynakları uygulamalarına yönelmişlerdir. Söz konusu uygulamalardan biri de çalışanların psikolojik olarak güçlendirilmesidir. Psikolojik güçlendirme, işletme yönetiminin desteğiyle çalışanın kendini yetkin ve yeterli hissetmesini ifade eder. Çalışanın psikolojik olarak güçlendirilmesi olumlu tutum ve davranışlar sergilemesinde son derece önemlidir. Çünkü yönetsel ve örgütsel konularda karar alma sürecine dâhil edilen, inisiyatif kullanabilen, iş süreçlerinde kendi kendine kararlar verebilen ve en önemlisi verdiği kararlar neticesinde ortaya çıkan sonuçların sorumluluğunu üstlenebilen çalışanlar örgüte zarar verici davranışlardan fazlasıyla kaçınacaktır. Ayrıca güçlendirilen çalışan bireysel ve örgütsel amaçlar arasında pozitif ilişkiler kuracak ve birçok olumlu davranış sergileyecektir.

İlgili literatür incelendiğinde, psikolojik güçlendirme algısının birçok olumlu davranışın (yöneticiye güven, örgütsel bağlılık, sinerjik iklim algısı ve yenilikçi davranış gibi) belirleyicisi olduğu görülmüştür (Balçık ve Ordu, 2019; Çalık ve Duman, 2020; Yanık ve Acar, 2020; Demirer, 2020). Bu araştırmada, psikolojik güçlendirme algısının belirleyicisi olduğu diğer bir olumlu davranışın da örgütsel özdeşleşme olduğu düşünülmektedir. Nitekim konu ile ilgili çalışmalar incelenmiş ve bu ilişkiyi ele alan birçok araştırmaya (Polat, Meydan ve Tokmak, 2010; Zhu, Sosik, Riggio ve Yang, 2012; Prati ve Zani, 2013: Kanbur, 2017) rastlanmıştır. Diğer yandan araştırmada kariyer memnuniyeti kavramı da dikkate alınmış ve psikolojik güçlendirmenin örgütsel özdeşleşme üzerindeki etkisinde kariyer memnuniyetinin katkısı belirlenmeye çalışılmıştır. Dolayısıyla araştırmada “psikolojik güçlendirme algısının örgütsel özdeşleşme duygusuna nasıl etki eder?" ve "bu etkide kariyer memnuniyeti aracılığı ile nasıl bir değişim gerçekleşir?" soruları cevaplanmaya çalışılmıştır. Bu doğrultuda alan yazında gerekli incelemeler yapılmıs ve hem ulusal hem de uluslararası literatürde psikolojik güçlendirme algısının örgütsel özdeşleşme üzerine etkisinde kariyer memnuniyetinin rolünü inceleyen araştırmaya rastlanmamıştır. Bu nedenle söz konusu üç değişkeni birlikte ele alan bu araştırmanın literatüre katkı sağlayacağı düşünülmektedir.

\section{Kavramsal Çerçeve}

\subsection{Psikolojik Güçlendirme}

Psikolojik güçlendirmenin temeli personel güçlendirme kavramının alt boyutlarından biri olarak oluşturulmuştur. Bu yönüyle personel güçlendirme, yapısal ve psikolojik güçlendirme olmak üzere iki temel yaklaşımla açıklanmaktadır (Laschinger, Finegan, Shamian ve Wilk, 2001: 261; Carless, 2004: 406). Yapısal yaklaşıma göre güçlendirme; bilginin ve gücün alt kademedeki çalışanlarla paylaşılmasıdır (Hales ve Klidas, 1998: 89). Yani gücün üst kademe yönetimden alt kademe çalışanlara iletilmesidir (Randolp ve Sashkin, 2002: 103). Gücün bu şekilde hiyerarşik bir şekilde aktarılmasıyla çalışanların sorumlulukları artmakta ve yönetimsel faaliyetlere katılım sağlamaktadırlar (Thomas ve Velthouse, 1990: 666). Bu sayede çalışanlar sorumlulukları yerine getirebilmek için çok daha fazla çalışmakta, bu durum ise örgütün amaçlarına ulaşmasını kolaylaştırmaktadır (Kerse ve Karabey, 2014: 25). Psikolojik güçlendirme ise; güçlendirilmenin yapılması için gerçekleştirilen çalışmaların çalışanlar tarafından nasıl algılandığına odaklanmaktadır (Spreitzer, 2005: 3). Yapısal güçlendirme yaklaşımında, güçlendirilen çalışanların psikolojik durumları dikkate alınmadığı düşüncesiyle psikolojik güçlendirme çalışmaları hız kazanmıştır (Conger ve Kanungo, 1988; Thomas ve Velthouse, 1990; Spreitzer, 1995). Nitekim bu araştırmada da psikolojik güçlendirme dikkate alınmıştır.

Psikolojik güçlendirme kavramı ilk kez Bandura (1986)'nın ortaya koyduğu öz yeterlilik kavramı ile yani "kişinin kendi yeteneğinin ve yeterliliğinin farkında olması ve buna inanması" ile ifade edilmiştir (Akt: Taştan, 2014: 95). Buna göre Conger ve Kanungo (1988: 474), Bandura (1986)'nın öz yeterlilik kavramından yararlanarak güçlendirmeyi "güçsüzlüğü artıran unsurların belirlenerek biçimsel veya biçimsel olmayan örgütsel uygulamalar yardımıyla çalışanların öz yeterlilik inanç seviyesinin yükseltilmesi" şeklinde tanımlamışlardır. Conger ve Kanungo (1988)'nun yapmış oldukları tanımdan esinlenen Thomas ve Velthouse 
(1990) ise, güçlendirmenin tek bir kavram ile değerlendirilmesinin mümkün olmadığını, güçlendirmenin çok boyutlu bir süreç olduğunu ve kişilerin algılamalarına bağlı olduğunu belirtmişlerdir. Bu doğrultuda Thomas ve Velthouse (1990: 669-670) güçlendirmeyi, çalışanın iş rolüne eğilimini gösteren anlamlılık, yetkinlik, seçim ve etki olmak üzere dört boyut ile ifade edilen içsel görev motivasyonu şeklinde tanımlamışlardır.

Psikolojik güçlendirme yaklaşımı ile ilgili önemli çalışmalar yapan bir diğer araştırmacı Spreitzer (1995) ise güçlendirmeyi "çalışanların işleriyle ilgili kararları, üst yönetimin müdahalesine gerek kalmadan karar vermelerini sağlayan yönetim anlayışı" olarak ifade etmiştir. Bununla birlikte Spreitzer (1995), Thomas ve Velthouse (1990)'un psikolojik güçlendirmeye yönelik sunduğu dört boyutlu yapıyı anlamlıık, yetkinlik, otonomi ve etki olarak yeniden tanımlamıştır. Bu boyutlar şu şekilde açıklanmaktadır:

- Anlamlıık: Çalışanın kendisine verilmiş olan görevi içsel olarak benimsemesi (Thomas ve Velthouse, 1990: 672); işin gerekleri ile çalışanın inanç, değer ve yargıları arasındaki uyumu ifade eder (Spreitzer, 1995: 1143). Anlamlılık seviyesinin düşük olması, önemli olaylara karşı umursamazlık ve ilgisizlik gibi olumsuz sonuçlara neden olurken; yüksek anlamlılık işe yönelik çabayı, katılımı ve örgütsel bağııı̆̆ı arttırabilmektedir (Spreitzer vd., 1997: 683).

- Yetkinlik: Çalışanın iş ile ilgili faaliyetleri gerçekleştirecek kapasiteye sahip olduğuna dair inancı ifade eder. Yani kişinin kendisini işi konusunda yeterli hissetmesi ve performansına güvenmesi anlamına gelmektedir (Spreitzer vd.,1997: 682). Yetkinlik seviyesinin yüksek olması durumunda çalışan insiyatif kullanır, daha fazla çalışmak için çabalar ve sorunlarla karşılaştığında sorunları ortadan kaldırmak için gayret sarf eder (Arslantaş, 2007: 230).

- Otonomi: Çalışanın işlerini nasıl yapacağına ilişkin karar verme özgürlüğünü ve işleri üzerindeki kontrol duygusunu ifade eder (Hu ve Leung, 2003: 368). Çalışanlara sunulan yüksek seviyede otonomi daha fazla esneklik, yaratıcılık, girişim ve dayanıklılık çıktıları sağlarken; düşük düzeydeki otonomi ise, çalışanların kendini denetim altında hissetmeleri ile negatif bir ruh haline, gerilime ve özsaygının azalmasına yol açabilmektedir (Thomas ve Velthouse, 1990: 673).

- Etki: Çalışanın önemli örgütsel çıktılar (stratejik, operasyonel veya yönetsel) üzerinde ne kadar etkili olduğunu ifade eder (Spreitzer, 1995: 1444). Dolayısıyla bu boyut, çalışanın iş yerinde bir iz bırakabilme ve örgütün çalışanın düşüncesini önemseme seviyesini göstermektedir (Yanık ve Açar, 2020: 64).

Araştırmacıların ortaya koymuş olduğu bu dört boyut birbirlerinin öncülü veya ardılı niteliğinde değildir. Söz konusu boyutlar güçlendirmenin farklı yönlerini belirtmektedir (Spreitzer vd, 1997: 681). Çalışanların bu boyutlarla ilgili algısı ne kadar fazla ve pozitif ise güçlendirme algısının da o kadar fazla olacağı vurgulanmaktadır. Ayrıca bu dört boyuttan birinin eksikliği durumunda güçlendirme algısının tamamen ortadan kalkmayacağı sadece etkisinin azalacağı belirtilmektedir (Spreitzer, 1995: 1443).

\section{2. Örgütsel Özdeşleşme}

Örgütsel özdeşleşme kavramının teorik temeli, kişilerin bireysel ve sosyal kimliklerinin olduğunu varsayan sosyal kimlik kuramına dayanmaktadır (Mael ve Ashforth, 1992: 104). Sosyal kimlik kuramına göre, bireyler öncelikle bir gruba katılır, grup üyeliğini dikkate alarak kendini tanımlar, değerlendirir, sınıflandırır ve daha sonra birey kendi benliğini farklı grup üyeleri ile karşılaştııır (Tajfel ve Turner, 1979: 41). Bu süreçte birey üyesi olduğu sosyal gruba ilişkin bazı bilgiler elde eder ve gruba karşı aidiyet hissederek sosyal özdeşleşme sağlanır (Ashfort ve Mael, 1989: 20-21). Bu kapsamda örgütsel özdeşleşme, sosyal özdeşleşmenin özel bir şekli olarak karşımıza çıkmakta ve kişinin üyesi olduğu örgütle bir olma algısı ve aidiyeti olarak tanımlanmaktadır (Mael ve Ashfort, 1992: 104).

Alan yazın incelendiğinde, örgütsel özdeşleşmeye yönelik genel geçer tek bir tanımın yapılmadığı ve özellikle 1970'lerden sonra kavramın daha çok ele alındığı görülmektedir. Örneğin Hall vd. (1970: 177) örgütsel özdeşleşmeyi; bireysel amaçlarla örgütsel amaçların birbiriyle bütünleşmesi ve uyumlu hale gelmesi şeklinde tanımlamışlardır. Lee (1971: 214-215), örgütsel özdeşleşmeyi “ait olma, sadakat ve ortak özellikler" olmak üzere üç boyutlu bir kavram olarak belirtmektedir. Dutton vd. (1994: 239)'ine göre örgütsel 
özdeşleşme, bireylerin örgütlerini tanımlarken kullandıkları anlatımları kendilerini ifade ederken de kullanabilmesidir. Rousseau (1998: 217) örgütsel özdeşleşmeyi, kişinin kendini örgütün büyük bir parçası olarak algılaması şeklinde tanımlarken; Knippenberg ve Schie (2000: 138)'ne göre örgütsel özdeşleşme, kişinin kısmen de olsa örgütünü temsil ettiğini düşünmesidir. Edwards (2005: 218) ise örgütsel özdeşleşmeyi psikolojik olarak örgütle ilişki kuran kişinin örgüt ile arasında bilişsel ve duyuşsal bir ilişkinin olduğunu algılaması şeklinde tanımlamıştır. Örgütsel özdeşleşme ile ilgili her ne kadar birçok farklı tanım yapılsa da örgütsel özdeşleşmenin, bireyin ait olduğu örgüte karşı kendisini nasıl hissettiğini ifade eden bir kavram olarak karşımıza çıktığı gözlenmektedir.

Örgütsel özdeşleşme, örgüt ile çalışan arasındaki bağı ifade ettiği için örgüt içerisindeki birçok davranışın öncülü ve ardılı olarak karşımıza çıkmaktadır. Nitekim Polat (2009: 95) çalışmasında; örgütsel adalet algısı, çalışma yaşamında özerklik, meslekle özdeşleşme, lider-liderlik, kariyer gelişimi, örgütsel güven, başarı fırsatı, ödül alma, iş temelli destek algısı, saygı görme ve örgüt içi rekabet gibi birçok faktörü örgütsel özdeşleşmenin öncülü olarak belirtirken; örgütsel vatandaşlık davranışı, yüksek çalışan performansı, çalışan devir hızı, değişim ve değişime direnç, işten kaytarma, örgüte finansal yardım, örgüte katılım konusunda diğer üyeleri teşvik, devamsızlık, diğer gruplarla çatışma, müşteri yönelimi ve tatmini, örgütsel faaliyetlere katıım, sürekli gelişime çabası, örgütsel bağlılık, motivasyon ve yöneticiden memnuniyet gibi faktörleri de örgütsel özdeşleşmenin ardılı olarak göstermiştir.

\subsection{Kariyer Memnuniyeti}

Bireylerin çalışma amaçları birbirinden farklı olsa da çalışmadaki asıl amaç, gereksinimlerin karşılanması ve tatmin edilmesi yönündedir. İş yaşamının ilk dönemlerinde temel ihtiyaçlarını karşılamak için çalışan birey, ilerleyen zamanda değişen, farklı istek ve ihtiyaçlarının tatmini için çaba göstermektedir (Yüksel, 2005: 305). Söz konusu farklı istek ve ihtiyaçlarından biri de kariyer memnuniyetidir.

Kariyer memnuniyeti, bireylerin iş deneyimleri sonucunda ortaya çıkan olumlu psikolojik sonuçlar ya da iş ile ilgili kazanımlar veya başarılar şeklinde tanımlanmaktadır (Judge, Cable, Boudreau ve Bretz, 1995: 486). Diğer bir tanımda ise kariyer memnuniyeti; bireyin mevcut kariyer başarılarına yönelik farkındalığı ve gelecekteki ilerlemeye ilişkin tahminleri olarak ifade edilmiştir (Kang, Gatling ve Kim, 2014: 72).

Kariyer memnuniyeti, bireylerin kendilerine özgü içsel ve dışsal algılamalarını içermektedir (Greenhaus vd., 1990: 65). Dolayısıyla kariyer memnuniyeti sübjektif ve objektif unsurları kapsamaktadır (Judge vd., 1995: 485). Sübjektif unsurlar, çalışanların kendi kariyerlerine yönelik olumlu/olumsuz algııları ile ilgiliyken; objektif unsurlar, çalışanların ücret, prim ve hiyerarşik statü gibi değişkenlere dair memnuniyet düzeylerini kapsamaktadır (Abele ve Spurk, 2009: 54).

Kariyer memnuniyeti ile ilgili yapılan araştırmalar sonucunda, kariyer memnuniyeti ile örgütsel bağlılık, işte kalma niyeti, örgütsel değişime destek olma, statü, maaş ve yenilikçi davranışlar gibi örgütsel unsurlar arasında pozitif ilişkilerin bulunduğu buna karşın işten ayrılma niyeti, tükenmişlik ve etik dışı davranışlar arasında negatif yönlü ilişkilerin olduğu belirtilmiştir (Çelik vd., 2014: 504; Kaya, 2018: 42).

\subsection{Değişkenler Arası Iliş̧silerin Tespiti ve Hipotezlerin Geliştirilmesi}

Çalışanların psikolojik güçlendirme algılarının örgütsel özdeşleşmeleri üzerinde önemli etkilerinin olduğu olasıdır. Nitekim Polat vd. (2010), personel güçlendirme, örgütsel sinizm ve örgütsel özdeşleşme arasındaki ilişkileri belirlemek için gerçekleştirdikleri araştırmada, personel güçlendirmenin örgütsel özdeşleşme üzerinde pozitif ve anlamlı bir etkisinin olduğunu belirlemişlerdir. Ertürk (2010) çalışmasında, çalışanların psikolojik güçlendirme algılarının artması onların örgütleri ile özdeşleşme düzeylerini arttırdığını tespit edilmiştir. Prati ve Zani (2013), psikolojik güçlendirme ve örgütsel özdeşleşme arasındaki ilişkiyi araştırdıklarında çalışmada, psikolojik güçlendirmenin örgütsel özdeşleşmeyi pozitif ve anlamlı olarak etkilediği sonucuna varmışlardır. Benzer şekilde Kanbur (2017) yapmış olduğu araştırmada, çalışanların psikolojik güçlendirme algılarının örgütsel özdeşleşmelerini pozitif yönde etkilediği sonucuna ulaşmıştır. Yapılan bu ampirik araştırma bulguları doğrultusunda araştırmada test edilmek üzere aşağıdaki hipotez geliştirilmiştir: 
$\boldsymbol{H}_{1}$ : Psikolojik gü̈clendirme algısının örgütsel özdeşleşme üzerinde pozitif yönlü bir etkisi vardır.

Çalışma yaşamında yer alan kişiler için kariyer hayatlarının bir parçası haline gelmektedir. Çünkü yaşamının önemli bir kısmını işte geçirmekte olan kişinin gelişmesi, statü edinimi, güç kazanma, yaptığı işte karar verebilme hakkına sahip olma gibi kazanımları ancak elde ettiği kariyerle mümkündür. Çalışanın söz konusu ilerleme sürecini gerçekleştirebilmesi ve elde ettiği kariyerinden memnun olması için çalıştığı ortamda güçlendirme sürecinin olması gerekmektedir. Bu doğrultuda, psikolojik güçlendirme algısı ile kariyer memnuniyeti arasındaki ilişkiyi araştıran çalışmalar (Haiyan vd., 2016; Dan vd., 2018; Demirer, 2020) bu iki kavram arasında pozitif yönlü bir ilişki olduğunu tespit etmişlerdir. Bu bilgilere ve daha önceki çalışma sonuçlarına dayanarak aşağıdaki hipotez oluşturulmuştur:

\section{$\boldsymbol{H}_{2}$ : Psikolojik güçlendirme algısının kariyer memnuniyeti üzerinde pozitif yönlü bir etkisi vardır.}

Kariyer memnuniyeti ve örgütsel özdeşleşme ile ilgili birçok araştırma olmasına rağmen her iki değişkeni birlikte ele alan araştırmaya rastlanmamıştır. Ancak örgütsel yaşam içerisinde kariyer memnuniyetinin örgütsel bağlılık, örgütsel değişimi destekleme ve örgütte kalma isteği gibi davranışlar ile pozitif yönde ilişkilerinin olduğu (Kaya, 2018) dikkate alındığında örgütsel özdeşleşme ile de pozitif yönlü bir ilişkisinin olduğu düşünülmekte ve aşağıdaki hipotez geliştirilmiştir:

$\boldsymbol{H}_{3}$ : Kariyer memnuniyetinin örgütsel özdeşleşme üzerinde pozitif yönlü bir etkisi vardır.

Psikolojik güçlendirme algısı, örgütsel özdeşleşme ve kariyer memnuniyeti değişkenlerinin birlikte ele alındığı herhangi bir araştırmaya da rastlanmamıştır. Ancak yukarıdaki araştırmalara dayanarak psikolojik güçlendirme algısının örgütsel özdeşleşmeyi arttırdığı varsayılmakta ve bu artışta kariyer memnuniyetinin de rolü olduğu tahmin edilmektedir.

$\boldsymbol{H}_{4}$ : Psikolojik güçlendirme algısının örgütsel özdeşleşme üzerine etkisinde kariyer memnuniyetinin aracılık etkisi vardır.

\section{Yöntem}

\subsection{Araştırmanın Amacı ve Önemi}

Araştırmada, "Psikolojik güçlendirme algısı örgütsel özdeşleşmeyi etkiler mi?" sorusundan hareketle, psikolojik güçlendirme algısının örgütsel özdeşleşmeye etkisi kariyer memnuniyeti aracı değişkeni dâhil edilerek incelenmiştir. Dolayısıyla araştırmanın amacı, katılımcıların psikolojik güçlendirme algısını belirleyerek örgütsel özdeşleşme üzerindeki etkisini ve bu etkide kariyer memnuniyetinin aracı rolünü belirlemektir.

Alan yazında psikolojik güçlendirme algısı, örgütsel özdeşleşme ve kariyer memnuniyeti ile ilgili çok sayıda araştırma bulunmaktadır. Ancak Türkçe ve İngilizce literatür taraması sonucunda söz konusu üç değişkeni birlikte inceleyen herhangi bir araştırmaya rastlanmamıştır. Bu nedenle araştırma bulgularının literatüre katkılar sağlayacağı düşünülmektedir.

\subsection{Araştırmanın Örneklemi}

Türkiye'de avukatlara yönelik psikolojik güçlendirme, kariyer memnuniyeti ve örgütsel özdeşleşme değişkenlerini ele alan bir çalışmanın olmayışı dikkat çekmektedir. Bu nedenle, örneklem sınırlılı̆ında kolay ulaşılabilirlik özelliği de dikkate alınarak, araştırmanın örneklemi Konya ilinde hukuk bürolarında çalışan iş̧̧i avukatlardan oluşmaktadır. Araştırmanın katılımcıları tesadüfî olmayan örnekleme yöntemine göre seçilen 262 avukattan oluşmaktadır. Yapısal eşitlik modeli için örneklem sayısının 201-300 aralığında olmasının yeterli olduğu belirtilmiş (Comfrey ve Lee, 1992: 217) ve bu araştırma için de yeterli örneklem sayısına ulaşılmıştır. 


\subsection{Araştırmanın Modeli}

Araştırmada genel tarama modeli kullanıımıştır. Araştırmanın bağımsı değişkeni psikolojik güçlendirme algısı, bağımlı değişkeni örgütsel özdeşleşme, aracı değişkeni ise kariyer memnuniyetidir. Araştırmanın modeli Şekil 1'de gösterilmiştir.

Şekil 1. Araştırmanın Kavramsal Modeli

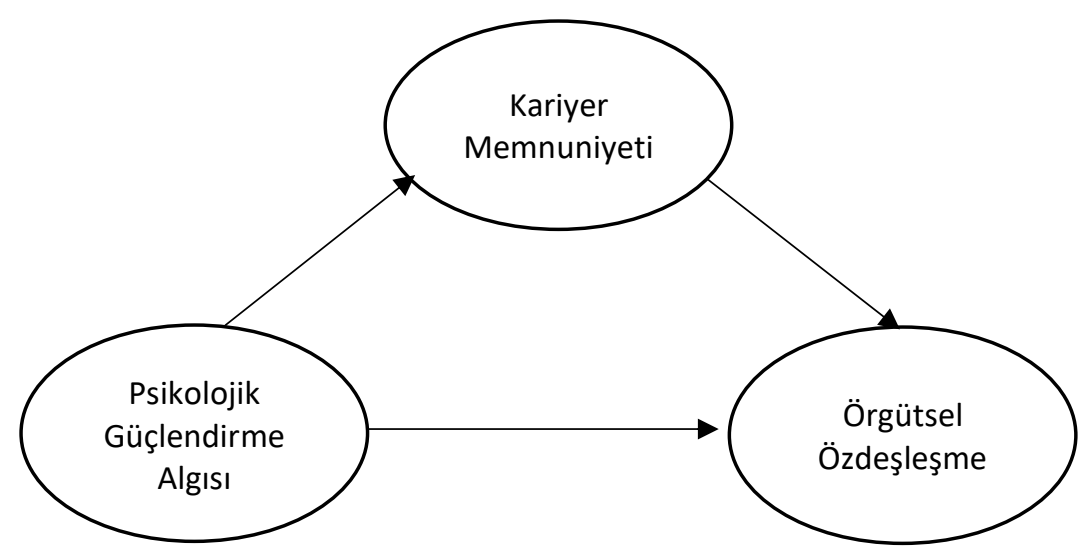

\subsection{Veri Toplama Yöntemi ve Kullanılan Ölçekler}

Nicel araştırma yönteminin kullanıldığı bu çalışmada, veri toplama aracı olarak anket tekniği kullanılmıştır. Anket formu https://www.google.com/intl/tr_tr/forms/about/ aracılığı ile internet tabanlı olarak hazırlanmış ve ilgili web sitesinden oluşturulan link, bizzat araştırmacı tarafından katılımcılarla yüz yüze görüşülerek telefonlarına, e-posta adreslerine ve çeşitli sosyal medya hesaplarına iletilmiştir. Araştırmaya ait veriler 21 Aralık 2020 ile 04 Ocak 2021 tarihleri arasında toplanmıştır.

Kullanılan anket formu "psikolojik güçlendirme algısı", "örgütsel özdeşleşme” ve "kariyer memnuniyeti" olmak üzere üç temel ölçekten oluşmaktadır. Katılımcıların psikolojik güçlendirme algısını belirlemede; Spreitzer (1995) tarafından geliştirilen, Sürgevil, Tolay ve Topoyan (2013) tarafından Türkçeye uyarlanan 12 madde ve dört boyuttan oluşan ölçek; örgütsel özdeşleşme düzeyini belirlemede Mael ve Ashforth (1992) tarafından geliştirilen, Tak ve Aydemir (2004) tarafından Türkçeye uyarlanan altı madde ve tek boyuttan oluşan ölçek; kariyer memnuniyetini belirlemede ise Greenhaus, Parasuraman ve Wormley (1990) tarafından geliştirilen, Kaya (2018) tarafından Türkçeye uyarlanan beş madde ve tek boyuttan oluşan ölçek kullanılmıştır. Ölçeklerdeki maddeler beşli Likert tipine (1-Kesinlikle Katılmıyorum, 5-Kesinlikle Katılıyorum) göre cevaplanmıştır.

\subsection{Araştırma Verilerinin Analizi}

Araştırma kapsamında elde edilen veriler SPSS 21.0 ve AMOS 21.0 programları kullanılarak değerlendirilmiştir. Araştırmada öncelikle ölçeklerin yapısal geçerliğini test etmeye yönelik doğrulayıcı faktör analizi (DFA), iç tutarlılı̆ının tespitinde ise güvenilirlik analizi yapılmıştır. Daha sonra araştırmada değişkenler arasındaki ilişkinin yönünü ve şiddetini belirlemek amacıyla korelasyon analizi, hipotezlerin sınanmasında ise yapısal eşitlik modellemesinden yararlanılmıştır. Ayrıca bahsi geçen analizlere ek olarak tanımlayıcı istatistiklerden frekans, yüzdelik, ortalama ve standart sapma değerlerine de yer verilmiştir.

\subsection{Araştırma Etiği}

Araştırmada veri toplama araçlarının kullanım izni için 30.11.2020 tarihli ve 97160 karar sayılı "Selçuk Üniversitesi Rektörlüğü Etik Kurul” kararı alınmıştır. 


\section{Bulgular}

\subsection{Demografik Özellikler}

Araştırmaya katılan 262 avukata ait demografik özellikler Tablo 1'de gösterilmiştir. Bu bulgulara göre; araştırmaya katılan avukatların \% 66,8'inin erkek, \%33,2'sinin kadın olduğu ve \%75,6'sının evli olduğu görülmektedir. Yaş dağılımı incelendiğinde, \%70,3 oranında çoğunluğunun 26-45 yaş aralığında olduğu belirlenmiştir. İ̧̧ deneyimi süresine bakıldığında ise 6-10 yıl $(32,8)$ ve 1-5 yıl $(\% 27,5)$ arasında çalışan avukatların fazla sayıda oldukları görülmektedir.

Tablo 1. Katılımcılara Ait Demografik Özellikler

\begin{tabular}{|l|l|c|c|}
\hline & Kategori & $\mathbf{N}$ & $\mathbf{\%}$ \\
\hline \multirow{3}{*}{ Cinsiyet } & Kadın & 87 & 33,2 \\
\cline { 2 - 4 } & Erkek & 175 & 66,8 \\
\hline \multirow{4}{*}{ Medeni Durum } & Evli & 198 & 75,6 \\
\cline { 2 - 4 } & Bekar & 64 & 24,4 \\
\hline \multirow{5}{*}{ İş Genubu } & 25 yaş ve altı & 24 & 9,1 \\
\cline { 2 - 4 } & $26-35$ & 96 & 36,6 \\
\cline { 2 - 4 } & $36-45$ & 88 & 33,7 \\
\cline { 2 - 4 } & 46 yaş ve üstü & 54 & 20,6 \\
\hline \multirow{5}{*}{} & 1 yıldan az & 17 & 6,5 \\
\cline { 2 - 4 } & $1-5$ yıl & 72 & 27,5 \\
\cline { 2 - 4 } & $6-10$ yıl & 86 & 32,8 \\
\cline { 2 - 4 } & $11-15$ yıl & 52 & 19,8 \\
\cline { 2 - 4 } & 16 yıl ve üzeri & 35 & 13,4 \\
\hline
\end{tabular}

\section{2. Ölçeklere İlişkin Geçerlilik, Güvenirlik ve Normal Dağılım Analiz Bulguları}

Araştırmada kullanılan ölçeklerin yapı geçerliliğini tespit etmek amacıyla doğrulayıcı faktör analizi (DFA) yapılmıştır. Ölçeklerin orijinal halinde verilmiş olan faktör dağılımlarının doğruluğunu belirlemek için birinci düzey tek ve çok faktörlü ayrıca ikinci düzey çok faktörlü DFA yapılmıştır. Analizde ölçekte yer alan ifadelerin standardize edilmiş regresyon katsayısının yani madde faktör yükünün 0,70 'den düşük olmamasına ve $p$ değerinin 0,05'ten büyük olmamasına dikkat edilmiştir (Hair vd., 2009: 679). Ayrıca analizde bazı uyum indeks değerlerini iyileştirmek için teorik yapıya uygun bir şekilde modifikasyon yapılmıştır (Diamantopoulos ve Siguaw 2000).

Öncelikle orijinalinde dört boyut olarak geliştirilmiş olan psikolojik güçlendirme ölçeğine uygulanan DFA analizi şekil 2'de sunulmuştur. Analiz sonucunda, madde faktör yüklerinin 0,70 'in üzerinde olduğu belirlenmiştir.

Araştırmada kullanılan örgütsel özdeşleşme ve kariyer memnuniyeti ölçeklerine de doğrulayıcı faktör analizi yapılmış ve sonuçları Şekil 3 ve Şekil 4'te gösterilmiştir. Her iki ölçekte yer alan madde faktör yüklerinin referans kriterini sağladığı söylenebilir. Yalnızca örgütsel özdeşleşme ölçeğinde uyum indeks değerlerini iyileştirmek için ÖÖ1 ile ÖÖ2 maddeleri arasında modifikasyon yapılmıştır. 
Şekil 2. Psikolojik Güçlendirme Ölçeğinin Doğrulayıcı Faktör Analizi

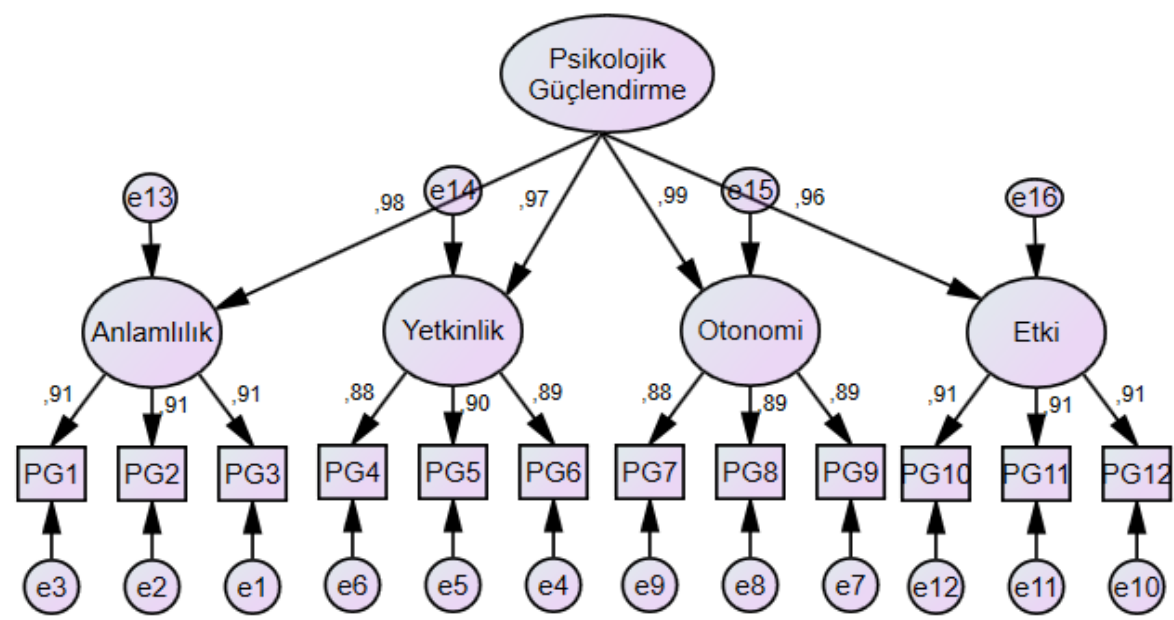

Şekil 3. Örgütsel Özdeşleşme Ölçeğinin Doğrulayıcı Faktör Analizi

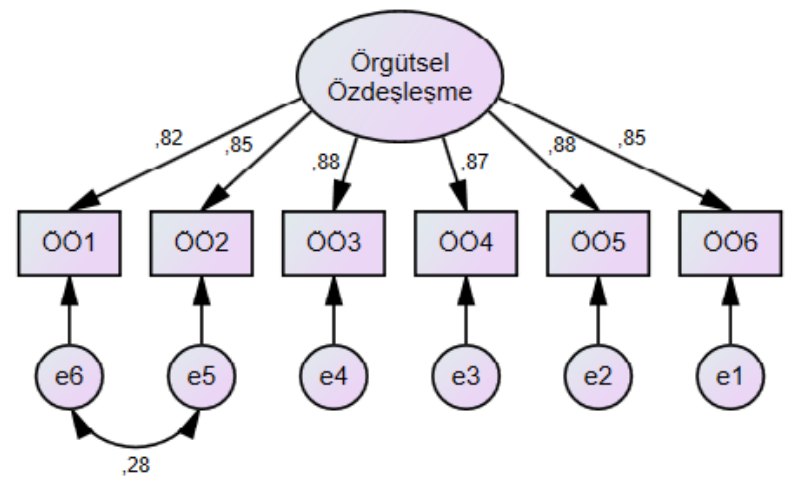

Şekil 4. Kariyer Memnuniyeti Ölçeğinin Doğrulayıcı Faktör Analizi

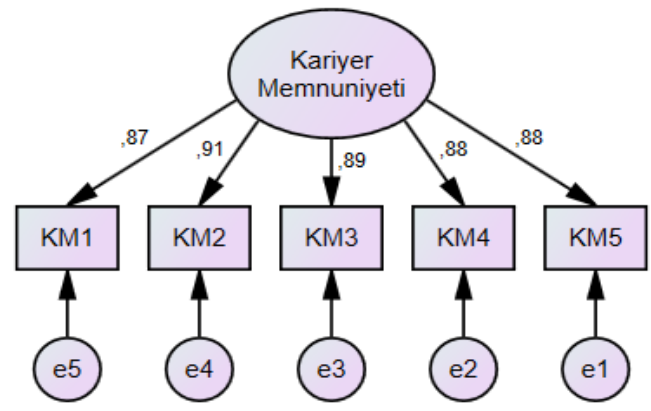

Tablo 2'de araştırmada kullanılan üç ölçeğe ait yapılan DFA analizi sonucunda elde edilen uyum indeks değerleri sunulmuştur. Bu kapsamda, ölçeklerde yer alan uyum indeks değerlerinin kabul edilebilir değerlere sahip olduklarını söylemek mümkündür.

Tablo 2. Ölçeklere Ait Uyum Değerleri

\begin{tabular}{|c|c|c|c|c|c|}
\hline Değişkenler & $\begin{array}{c}\text { CMIN/DF } \\
(0<\chi 2 / s d \leq 5)\end{array}$ & $\begin{array}{c}\text { RMR } \\
(\leq 0,10)\end{array}$ & $\begin{array}{c}\text { IFI } \\
(\geq 0,90)\end{array}$ & $\begin{array}{c}\text { CFI } \\
(\geq 0,90)\end{array}$ & $\begin{array}{l}\text { RMSEA } \\
(\leq 0,90)\end{array}$ \\
\hline Psikolojik Güçlendirme & 2,87 & 0,273 & 0,976 & 0,976 & 0,085 \\
\hline Örgütsel Özdeşleşme & 2,66 & 0,016 & 0,990 & 0,990 & 0,080 \\
\hline Kariyer Memnuniyeti & 1,83 & 0,007 & 0,998 & 0,998 & 0,026 \\
\hline
\end{tabular}


Araştırmada kullanılan ölçeklere ilişkin yapılan güvenirlik analizi sonucunda Cronbach alfa katsayıları Tablo 3'te gösterilmiştir. Elde edilen bulgular, her üç ölçeğin de yüksek iç tutarlılığa sahip olduğunu ifade etmektedir.

Tablo 3. Güvenirlik Analizi

\begin{tabular}{|l|c|c|}
\hline & Cronbach's Alpha & Madde Sayısı \\
\hline Psikolojik Güçlendirme & 0,976 & 12 \\
\hline Örgütsel Özdeşleşme & 0,945 & 6 \\
\hline Kariyer Memnuniyeti & 0,948 & 5 \\
\hline
\end{tabular}

Parametrik hipotez testlerinin uygulanabilmesi için verilerin normal dağılım gösterip göstermediğinin belirlenmesi en önemli şartlardan biridir (Terzi, 2019: 200). Bu doğrultuda, verilerin normal dağılıma uygunluğunu belirlemek için çarpıklık ve basıklık değerleri incelenmiştir. Normal dağılım için Tabachnick ve Fidel (2013)'ün belirlediği aralıklar (+1,50 ve $-1,50)$ dikkate alındığında; kullanılan ölçeklerin çarpıklık ve basıklık değerlerinin normal dağılıma uygun olduğu saptanmıştır.

\subsection{Değişkenlere Ait Betimleyici İstatistikler ve Korelasyonlar}

Araştırmada kullanılan verilerin normal dağı̆ım göstermesi nedeniyle değişkenler arasındaki ilişkiyi belirlemek amacıyla Pearson korelasyon analizi kullanılmış ve elde edilen sonuçlar Tablo 4'te gösterilmiştir.

Tablo 4. Değişkenlerin Ortalaması, Standart Sapması ve Korelasyon Katsayıları

\begin{tabular}{|l|c|c|c|c|c|c|c|c|c|}
\hline & $\overline{\mathbf{X}}$ & $\mathbf{S S}$ & $\mathbf{1}$ & $\mathbf{2}$ & $\mathbf{3}$ & $\mathbf{4}$ & $\mathbf{5}$ & $\mathbf{6}$ & $\mathbf{7}$ \\
\hline $\begin{array}{l}\text { 1.Psikolojik } \\
\text { Güçlendirme }\end{array}$ & 3,92 & 0,953 & 1 & & & & & & \\
\hline 2.Anlamlılık & 3,92 & 0,947 & $0,956^{* *}$ & 1 & & & & & \\
\hline 3.Yetkinlik & 4,02 & 0,983 & $0,947^{* *}$ & $0,918^{* *}$ & 1 & & & & \\
\hline 4.Otonomi & 3,88 & 1,013 & $0,961^{* *}$ & $0,883^{* *}$ & $0,863^{* *}$ & 1 & & & \\
\hline 5.Etki & 3,87 & 1,056 & $0,949^{* *}$ & $0,854^{* *}$ & $0,838^{* *}$ & $0,915^{* *}$ & 1 & & \\
\hline $\begin{array}{l}\text { 6.Örgütsel } \\
\text { Özdeşleşme }\end{array}$ & 3,96 & 0,892 & $0,821^{* *}$ & $0,792^{* *}$ & $0,796^{* *}$ & $0,777^{* *}$ & $0,768^{* *}$ & 1 & \\
\hline $\begin{array}{l}\text { 7.Kariyer } \\
\text { Memnuniyeti }\end{array}$ & 3,89 & 1,180 & $0,693^{* *}$ & $0,668^{* *}$ & $0,670^{* *}$ & $0,658^{* *}$ & $0,647^{* *}$ & $0,757^{* *}$ & 1 \\
\hline$* *$ p<0,01 & & & & & & & \\
\hline
\end{tabular}

Tablo 4'te her bir değişkenin ortalaması, standart sapması ve diğer değişkenler ile ilişkisini gösteren korelasyon katsayıları yer almaktadır. Tablo 4'teki ortalamalara göre, hukuk bürolarında çalışan avukatların psikolojik güçlendirme algısının yüksek $(\bar{x}=3,92)$ olduğu ve çalıştıkları iş yeri ile özdeşleştikleri $(\bar{x}=3,96)$ belirlenmiştir. Diğer yandan elde edilen bulgulara göre örneklemdeki avukatların genel olarak kariyer memnuniyetleri yüksek $(\bar{x}=3,89)$ düzeydedir.

Tablo 4'teki korelasyon bulguları incelendiğinde; psikolojik güçlendirme algısı ile örgütsel özdeşleşme arasında yüksek seviyede pozitif yönlü $(r=0,821)$; psikolojik güçlendirme algısı ile kariyer memnuniyeti arasında orta seviyede pozitif yönlü $(r=0,693)$ anlamlı bir ilişki tespit edilmiştir. Ayrıca örgütsel özdeşleşme ile kariyer memnuniyeti arasında da yüksek seviyede pozitif yönlü $(r=0,757)$ bir ilişki belirlenmiştir. Dolayısıyla psikolojik güçlendirme algısı hem örgütsel özdeşleşme duygusunu hem de kariyer memnuniyetini artırırken; örgütsel özdeşleşme duygusunun artması da kariyer memnuniyetini artırmaktadır. 


\subsection{Araştırma Hipotezlerinin Testi}

Araştırmalarda aracı rolünün tespit edilmesi için üç şartın yerine getirilmesi gerekir. Söz konusu şartlar aşağıdaki gibi sıralanmaktadır (Baron ve Kenny, 1986: 1176):

1. Bağımsız değişkenin bağımlı değişken üzerinde anlamlı bir etkiye sahip olması,

2. Bağımsız değişkenin aracı değişken üzerinde anlamlı bir etkiye sahip olması,

3. Bağımsız değişken ve aracı değişken ikisi birlikte bağımlı değişken üzerinde anlamlı bir etkiye sahip olurken, aracı değişken modele dâhil edildiğinde bağımsız değişkenin bağımlı değişkene yaptığı etkinin anlamsızlaşması veya azalması gerekmektedir.

Eğer üçüncü koşulda bağımsız değişkenin bağımlı değişken üzerindeki etkisi azalıyor ise kısmı aracı rolünden; etkisi anlamsızlaşmış ise tam aracı rolünden bahsetmek mümkündür.

Yukarıda verilen bilgiler doğrultusunda, araştırma amacında belirlenen etkileri tespit etmek için yapısal eşitlik modellemesinden yararlanılmıştır. Ancak Anderson ve Gerbing (1988)'in ortaya koydukları yaklaşıma göre; yapısal eşitlik modeline geçilmeden önce ölçüm modelinin test edilerek yeterli uyum indekslerine sahip olup olmadığının belirlenmesi gerekmektedir. Bu nedenle öncelikle modele DFA uygulanmış ve analiz sonucunda modele ait uyum indeksleri; $C M I N / D F=2,19 ; R M R=0,074 ; I F I=0,978 ; C F I=$ 0,$977 ;$ RMSEA $=0,068$ olarak belirlenmiştir. Yapılan analiz sonucunda, modele ait indeks değerlerinin kabul edilebilir uyum iyiliği değerleri kapsamında olduğu anlaşılmıştır. Dolayısıyla buradan hareketle yapısal eşitlik modeli (YEM) sonucunda verilerin iyi bir uyuma sahip olduğunu söylemek mümkündür.

Ölçüm modelinin sınanmasının ardından hipotezlerin test edilmesi için yapısal eşitlik modellemesi yapılmıştır. Bu kapsamda ilk adımda psikolojik güçlendirme algısının örgütsel özdeşleşme üzerindeki etkisi test edilmiştir (Şekil 5).

Şekil 5. Psikolojik Güçlendirme Algısının Örgütsel Özdeşleşmeye Etkisi

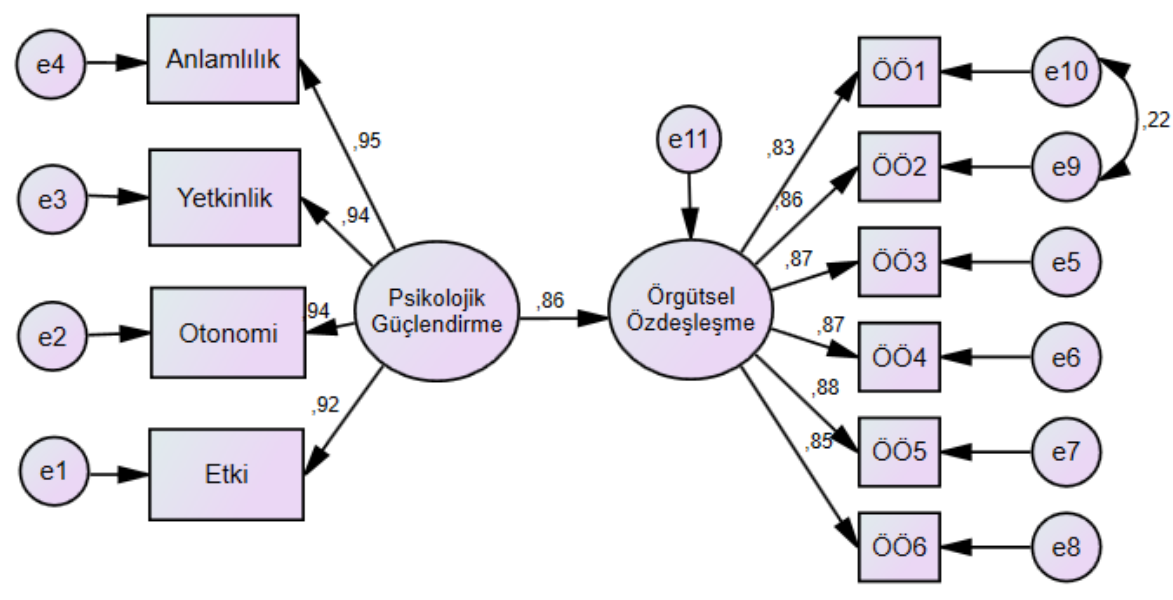

Elde edilen sonuçlar (CMIN/DF =3,79; RMR =0,091; IFI =0,970; $C F I=0,970 ; R M S E A=0,084$ ) model ile verilerin kabul edilebilir uyum sağladığını göstermektedir. Şekil 5 'te psikolojik güçlendirme algısının örgütsel özdeşleşmeyi pozitif ve anlamlı bir şekilde etkilediği $(\beta=0,86 ; p<0,001)$ görülmekte ve $H_{1}$ hipotezi desteklenmektedir. Ayrıca analiz sonucunda, örgütsel özdeşlemedeki varyansın \%73'ünün psikolojik güçlendirme algısı tarafından açıklandığı sonucuna ulaşılmıştır.

Araştırmanın ikinci adımında psikolojik güçlendirme algısının örgütsel özdeşleşme üzerindeki etkisinde kariyer memnuniyetinin aracı rolünün olup olmadığını belirlemek amacıyla kariyer memnuniyeti değişkeni potansiyel bir değişken olarak modele dâhil edilmiştir (Şekil 6). 
Şekil 6. Yapısal Eşitlik Modeli

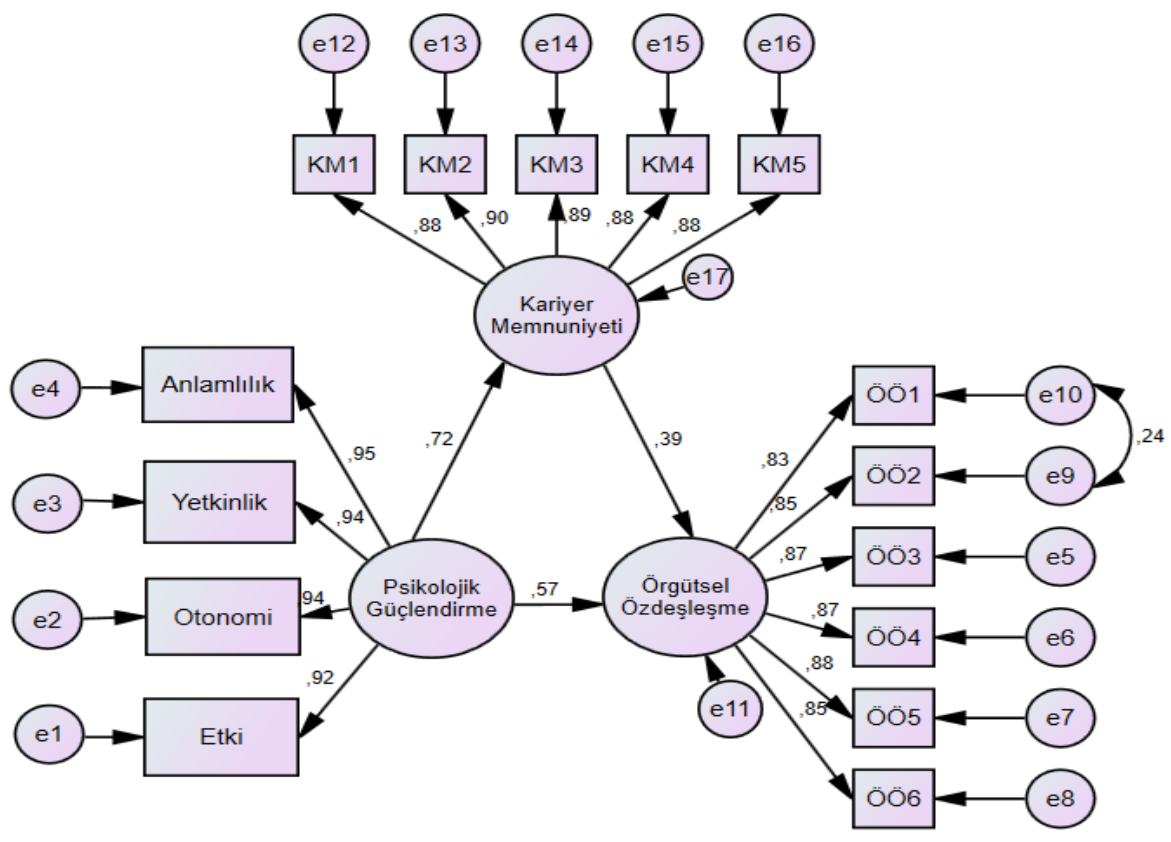

Şekil 6'daki yapısal eşitlik modelindeki yol analizleri incelendiğinde, psikolojik güçlendirmeden kariyer memnuniyetine giden yol ve kariyer memnuniyetinden örgütsel özdeşleşmeye giden yol pozitif ve anlamlıdır $(\beta=0,72, p<0,001 ; \beta=0,39, p<0,001)$. Bu doğrultuda $\mathrm{H}_{2}$ ve $\mathrm{H}_{3}$ hipotezleri desteklenmektedir. Ancak ilk adımda psikolojik güçlendirmeden örgütsel özdeşleşmeye giden anlamlı yol kariyer memnuniyetinin analize dahil edilmesiyle anlamsızlaşmamış sadece üzerindeki etkisi azalmıştır. Bu durumda, psikolojik güçlendirme algısının örgütsel özdeşleşme üzerindeki etkisinde kariyer memnuniyetinin aracı etkisinin olduğunu söylemek mümkündür. Dolayısıyla araştırmada geliştirilen $\mathrm{H}_{4}$ hipotezi de desteklenmektedir.

\section{Sonuç}

İ̧ yaşamında insan kaynağının önemi anlaşıldıkça yöneticiler veya işletme sahipleri çalışanların örgütle özdeşleşmeleri, örgüte olan bağlılıkları, sadakatleri, işten tatmin olmaları gibi birçok konuda daha duyarlı hale gelmektedir. Söz konusu olumlu davranışların desteklenmesi için de çalışanlara psikolojik güçlendirme faaliyetleri kapsamında çeşitli destekler verilmektedir. Bu desteklerin hedeflenen boyutlarda nihai sonuca ulaşması durumunda ise hem örgüt hem de çalışan için "kazan-kazan" mantığı kapsamında her iki tarafa da fayda sağlayabilecektir.

Araştırmada avukatlar için önem arz eden, bireyin çalıştığı yer ile bütünleşmesini ve kendisini örgütün bir parçası olarak algılamasını ifade eden örgütsel özdeşleşme ve kariyer memnuniyeti kavramları ele alınmış ve örneklem kapsamındaki avukatların örgütsel özdeşleşme ve kariyer memnuniyeti seviyeleri incelenmiştir. Avukatlık gibi rekabetin yoğun, iş yükünün ve iş stresinin fazla olduğu iş gruplarında verimliliğin sağlanması açısından örgütsel özdeşleşme ve kariyer memnuniyeti önem arz etmektedir. Diğer yandan araştırmada hukuk bürolarında çalışan avukatların psikolojik güçlendirme algısının örgüt ile özdeşleşmelerinde kariyer memnuniyetinin rolü belirlenmiştir. Nitekim literatürde psikolojik güçlendirme algısının örgütsel özdeşleşmeye etkisinde kariyer memnuniyetinin aracı rolünü ele alan çalışmaya rastlanmamıştır.

Araştırmada yapılan betimsel istatistik sonucuna göre, hukuk bürolarında çalışan avukatların hem psikolojik güçlendirme algılarının hem örgütsel özdeşleşmelerinin hem de kariyer memnuniyetlerinin yüksek düzeyde olduğu söylenebilir. İkinci bir değerlendirme ise bağımlı, bağımsız ve aracı değişkenler arasındaki ilişkilere yöneliktir. Yapılan Pearson korelasyon analizi sonucunda, avukatların psikolojik güçlendirme algısı ile örgütsel özdeşleşmeleri arasında yüksek düzeyde, kariyer memnuniyetleri ile orta düzeyde pozitif yönlü anlamlı ilişkilerin olduğu tespit edilmiştir. Ayrıca örgütsel özdeşleşme ile kariyer memnuniyeti arasında da 
yüksek düzeyde pozitif yönlü anlamlı ilişki ortaya çıkmıştır. Bu sonuç psikolojik güçlendirme algılayan çalışanın hem örgütüyle özdeşleştiği hem de kariyerinde memnuniyet duyduğu anlamına gelmektedir.

Değişkenler arasındaki korelasyon belirlendikten sonra hipotezlerin test edilmesine geçilmiştir. Hipotezlerin testi için yapısal eşitlik modellemesinden yararlanılmıştır. Bu doğrultuda ilk olarak "psikolojik güçlendirme algısı örgütsel özdeşleşmeyi etkiler mi? araştırma sorusu referans alınarak oluşturulan $\mathrm{H}_{1}$ hipotezi sınanmış ve yapılan analiz sonucunda psikolojik güçlendirme algısının örgütsel özdeşleşmeyi pozitif ve anlamlı bir şekilde etkilediği belirlenmiştir. Böylelikle hem araştırma sorusunun cevabı karşılık bulmuş hem de $\mathrm{H}_{1}$ hipotezi desteklenmiştir. Elde edilen bu sonuç önceden yapılan araştırmaların (Polat vd., 2010; Zhu vd., 2012; Prati ve Zani, 2013: Kanbur, 2017) sonuçlarıyla da benzerlik göstermiştir. Sonuç itibariyle çalışanın işletme yönetiminin desteğiyle kendini yetkin ve yeterli hissetmesi örgütüyle özdeşleşmesini sağlamıştır.

Araştırmanın ikinci adımında psikolojik güçlendirme algısının örgütsel özdeşleşme üzerindeki etkisinde kariyer memnuniyetinin aracı rolünün olup olmadığını belirlemek amacıyla kariyer memnuniyeti değişkeni potansiyel bir değişken olarak analize dâhil edilmiştir. Analiz sonucunda psikolojik güçlendirme algısının kariyer memnuniyetini pozitif ve anlamlı yönde etkilediği tespit edilmiş ve $\mathrm{H}_{2}$ hipotezi desteklenmiştir. Bu doğrultuda avukatların psikolojik güçlendirme algılarının hem örgütsel özdeşleşmeleri hem de kariyer memnuniyetleri üzerinde olumlu yönde etkililerinin olduğu saptanmıştır. Ayrıca kariyer memnuniyetinin örgütsel özdeşleşmeyi olumlu yönde etkilediği sonucuna ulaşılmış ve $\mathrm{H}_{3}$ hipotezi de desteklenmiştir. Araştırmadaki son bulgu psikolojik güçlendirme algııının örgütsel özdeşleşmeye etkisinin doğrudan olmakla birlikte kariyer memnuniyeti üzerinden dolaylı olarak da olduğu yönündedir. Diğer bir ifadeyle, psikolojik güçlendirme algısının örgütsel özdeşleşmeye etkisinde kariyer memnuniyetinin de aracı etkisinin olduğudur. Bu durumda $\mathrm{H}_{4}$ hipotezi desteklenmiştir.

Araştırmadan elde edilen bu bulgular, çalışmanın çıkış noktasında mevcut düşünce ve belirsizliklere yönelik açıklayııı ve destekleyici veriler sunmuştur. Araştırma sonuçları da göstermektedir ki; bireyin yaptığı iş ile içselleşmesi, iş ile ilgili faaliyetleri gerçekleştirecek kapasiteye sahip olduğuna dair inancı, işlerini nasıl yapacağına ilişkin karar verme özgürlüğü ve işleri üzerindeki kontrol duygusu, örgütsel çıktılar üzerindeki etkisi gibi algılar yani bir bütün olarak psikolojik güçlendirme algısı tutum ve davranışlarını etkileyerek örgütle bütünleşmesini sağlamakta ve kariyerine yönelik olumlu duygular geliştirmesini desteklemektedir.

Avukatların mesleği gereği girişken, kendine güvenen, dışa dönük olma gerekleri, faaliyetlerini ülkenin bütün bölgelerinde mesai sınırlaması olmaksızın devam ettirmeleri, birden fazla dava ile ilgilenmeleri, mesleğe yönelik kariyer hedefleri, meslekte maddi ve manevi kazanç elde etme potansiyeli göz önünde bulundurulduğunda elde edilen bulguların beklentilerle uyumlu olduğu söylenebilir. Öte yandan işçi avukatların psikolojik güçlendirme algısının örgütsel özdeşleşme ve kariyer memnuniyetleri üzerinde etkili olduğunun bulunması avukatlık mesleğinde yönetimin desteğiyle çalışanın kendini yetkin ve yeterli hissetmesi bireyin çalıştığı kurumla bütünleşmesine ve kariyerinden keyif almasına yardımcı olduğu şeklinde yorumlanabilir. Ayrıca işçi avukatların çalıştığı kurumla özdeşleşmelerinde sadece psikolojik güçlendirme algısının yeterli olmadığı kariyerlerinden memnun olmalarının da etkisi olduğu söylenebilir. Bu durumda örgütsel özdeşleşmenin örgüt içerisindeki birçok olumlu davranışın ardılı olduğu dikkate alındığında, hukuk bürolarındaki işçi avukatların psikolojik olarak daha fazla güçlendirilmesi ve kariyer memnuniyetlerinin artırılması gerekmektedir.

Bu çalışmanın alan yazındaki eksiklikleri gidereceği, bu alanda yapılacak olan farklı ve yeni çalışmalara öncü olması umulmaktadır. Bu nedenle gelecekte yapılması planlanan araştırmalarda, psikolojik güçlendirme algısının örgütsel özdeşleşmeye etkisinde kariyer memnuniyetinin aracı etkisini içeren farklı sektör ve örneklem grupları ile araştırmalar yapılması önerilebilir. Çünkü psikolojik güçlendirme ile örgütsel özdeşleşme arasındaki ilişkide kariyer memnuniyetinin rolünü ele alan çalışmaların kurum veya sektör bazında yapılması, sonuçların genelleştirilmesine ve karşılaştırmaların yapılmasına imkân sağlanabilmesi açısından yararlı olacağı düşünülmektedir.

Diğer araştırmalarda olduğu gibi bu araştırmada kısıtlı imkânlar kapsamında gerçekleştirilmiştir. Bu kısıtları şu şekilde özetlemek mümkündür: Araştırmada ulaşılabilirlik nedeniyle tek bir ilde bulunan işçi avukatlar örneklem olarak belirlenmiştir. Dolayısıyla araştırma sonuçlarının, işçi avukatlar kapsamında 
genellenmesi mümkün değildir. Genellemenin yapılabilmesi için yapılacak olan araştırmalarda farklı illerdeki işçi avukatların da örnekleme dâhil edilmesi gerekmektedir. Araştırmanın diğer bir kısıtı ise araştırma değişkenleri eş zamanlı ölçüldüğü için nedensel olarak sonuç çıkarımlarının yapılamamasıdır. Dolayısıyla konu ile ilgili yapılacak boylamsal çalışmalar ileride yapılması planlanan araştırmalar açısından önem arz etmektedir.

\section{Beyan ve Açıklamalar (Declarations and Disclosures)}

Yazarların Etik Sorumlulukları (Ethical Responsibilities of Authors): Bu çalışmanın yazarı, araştırma ve yayın etiği ilkelerine uyduğunu kabul etmektedir.

Etik Kurul Onayı (Ethical Approval): Araştırmada veri toplama araçlarının kullanım izni için Selçuk Üniversitesi Sosyal ve Beşeri Bilimler Bilimsel Araştırma ve Yayın Etik Kurulu'ndan 97160 sayı ve 30.11.2020 tarihli etik kurul onayı alınmıştır.

Çıkar Çatışması (Conflicts of Interest): Yazar tarafından herhangi bir çıkar çatışması beyan edilmemiştir.

Finansal Destek (Funding): Yazar, çalışmanın hazırlanması ve/veya yayınlanması sürecinde herhangi bir finansal destek almamıştır.

Yazar Katkı Oranı (Author Contributions): Yazar; kavramlaştırma ve çalışma dizaynı, verilerin toplanması, verilerin analizi ve sonuçların yorumlanması, çalışmanın ilk/taslak halinin yazılması, çalışmanın gözden geçirilmesi ve düzenlenmesi/düzeltilmesi aşamalarından tek başına sorumlu olduğunu beyan etmektedir.

intihal Denetimi (Plagiarism Checking): Bu çalışma, intihal tarama programı kullanılarak intihal taramasından geçirilmiştir.

\section{Kaynaklar}

Abele, A. E., \& Spurk, D. (2009). The longitudinal impact of self-eficacy and career goals on objective and subjective career success. Journal of Vocational Behavior, 74(1), 53-62.

Arslantaş, C. C. (2007). Güçlendirici lider davranışının psikolojik güçlendirme üzerindeki etkisini belirlemeye yönelik görgül bir araştırma. Anadolu Üniversitesi Sosyal Bilimler Dergisi, 7(2), 227-240.

Balçık, E., \& Ordu, A. (2019). Örgüt kültürü psikolojik güçlendirme ve örgütsel bağlıık arasındaki ilişkiler. Uludağ Üniversitesi Eğitim Fakültesi Dergisi, 32(1), 93-119.

Baron, R. M., \& Kenny, D. A. (1986). The moderator-mediator variable distinction in social psychological research: Conceptual, strategic and statistical considerations. Journal of Personalityand Social Psychology, 51(6), 11731182.

Carless, S. A. (2004). Does Psychological empowerment mediate the relationship between psychological climate and job satisfaction? Journal of Business and Psychology, 18(4), 405-425.

Comfrey, A. L., \& Lee, H. B. (1992). A first course in factor analysis. ABD: Hillsdale Lawrence Erlbaum Associates.

Conger, J. A., \& Kanungo, R. N. (1988). The empowerment process: Integrating theory and practice. Academy of Management Review, 13(3), 471-482.

Dan, X., Xu, S., Liu, J., Hou, R., Liu, Y., \& Ma, H. (2018). Relationships among structural empowerment, innovative behaviour, self-efficacy, and career success in nursing field in Mainland China. Inter-national Journal of Nursing Practice, 24(5), 1-9.

Demirer, C. M. (2020). Yapısal ve psikolojik güçlendirmenin kariyer tatmini ve yenilikçi iş davranışı üzerine etkisi. Eskişehir Osmangazi Üniversitesi IiBF Dergisi, 15(1), 165-184.

Diamantopoulos, A., \& Siguaw, A. J. (2000). Introducing LISREL: A Guide for the uninitiated (Introducing statistical methods series). London: SAGE Publications.

Duman, Ş. A., \& Çalık, T. (2020). Ortaöğretim öğretmenlerinde psikolojik güçlendirmenin yordayıcıları olarak yapısal güçlendirme yöneticiye güven ve lider üye etkileşimi. The Journal of Academic Social Science Studies, 13(82), 6196.

Dutton, J. E., Dukerich, J. M., \& Harquail, C. V. (1994). Organizational images and member identification. Administrative Science Quarterly, 39, 239-263. 
Psikolojik Güçlendirme Algısının Örgütsel Özdeşleşme Üzerindeki Etkisinde Kariyer Memnuniyetinin Aracılık Rolü

Edwards, M. R. (2005). Organizational identification: A conceptual and operational review. International Journal of Management Reviews, 7(4), 207-230.

Greenhaus, J. H. Parasurama, S., \& Wormley, W. M. (1990). Effects of race on organizational experiences, job performance evaluations, and career outcomes. Academy of Management Journal, 33, 64-86.

Hair, J. F., Black W. C., Babin, B. J., \& Anderson, R. E. (2009). Multivariate data analysis (Seventh Edition). London: Pearson.

Hales, C., \& Klidas, A. (1998). Empowerment in five-star hotels: Choice, voice or rhetoric? Contemporary Hopitality Management, 10(3), 88-95.

Hall, D. T., Schneider, B., \& Harold, T. N. (1970). Personal factors in organizational identification. Administrative Science Quarterly, 15(2), 176-190.

Haiyan, K., Sun, N., Yan, Q. (2016). New generation, psychological empowerment: Can empowerment lead to career competencies and career satisfaction? International Journal of Contemporary Hospitality Management, 28(11), 2553-2569.

Hu, S. L., \& Leung, L. (2003). Effects of expectancy-value, attitudes, and use of the internet on psychological empowerment experienced by chinese women at the workplace. Telematics and Informatics, 20(4), 365-382.

Judge, T. A., Cable, D. M., Boudreau, J. W., \& Bretz, R. D. (1995). An empirical investigation of the predictors of executive career success. Personnel Psychology, 48, 485-519.

Kanbur, E. (2017). Psikolojik güçlendirme ve örgütsel özdeşleşme arasında birey-örgüt uyumunun aracı rolü. Uluslararası Sosyal ve Eğitim Bilimleri Dergisi, 4(7), 63-82.

Kang, H. J., Gatling, A., \& Kim, J. (2014). The impact of supervisory support on organizational commitment, career satisfaction, and turnover intention for hospitality frontline employees. Journal of Human Resources in Hospitality \& Tourism, 14(1), 68-89.

Kaya, A. (2018). Kariyer gelişim sürecinin örgütsel bağılık ve işten ayrılma niyeti üzerine etkisinin yapısal eşitlik modellemesi ile test edilmesi. Hitit Üniversitesi Sosyal Bilimler Enstitüsü, Doktora Tezi, Çorum.

Kerse, G., \& Karabey, C. N. (2014). Personel güçlendirme ile bireyin yaratıcılık algısı arasındaki ilişki: Bankacılık sektöründe bir uygulama. Akdeniz i.i.B.F. Dergisi, (29), 22-41.

Knippenberg, D. V., \& Schie, E. C. M. V. (2000). Foci and correlates of organizational identification. Journal of Occupational and Organizational Psychology, 73, 137-147.

Laschinger, H. K. S., Finegan, J., Shamian, J., \& Wilk, P. (2001). Impact of structural and psychological empowerment on job strain in nursing work settings: expanding kanter's model. Journal of Nursing Administration, 31(5), $260-272$.

Lee, S. M. (1971). An empirical analysis of organizational identification. Academy of Management Journal, 14(2), 213226

Mael, F., \& Ashforth, B. E. (1992). Alumni and their alma mater: A partial test of the reformulated model of organizational identification. Journal of Organizational Behavior, 13(2), 103-123.

Polat, M. (2009). Örgütsel özdeşleşmenin öncülleri ve ardılları üzerine bir saha araştırması. Uludağ Üniversitesi Sosyal Bilimler Enstitüsü, Doktora Tezi, Bursa.

Polat, M., Meydan, H., \& Tokmak, G. (2010). Personel güçlendirme-örgütsel sinizm ilişkisinde örgütsel özdeşleşmenin aracılık etkisi. 9. Ulusal İşletmecilik Kongresi Bildiri Kitabı (ss. 542-548).

Prati, G., \& Zani, B. (2013). The relationship between psychological empowerment and organizational identification. Journal of Community Psychology, 41(7), 851-866.

Randolp, W. A., \& Sashkin, M. (2002). Can organizational empowerment work in multinational settings? Academy of Management Executive, 16(1), 102-115.

Rousseau, D. M. (1998). Why workers still identify with organizations. Journal of Organizational Behavior, 19, $217-233$.

Spreitzer, G. M. (1995). Psychological empowerment in the workplace: Dimensions, measurement, and validation. Academy of Management Journal, 38(5), 1442-1465.

Spreitzer, G. M., Kizilos, M. A., \& Nason, S. W. (1997). A dimensional analysis of the relationship between psychological empowerment and effectiveness satisfaction and strain. Journal of Management, 23(5), 679-704.

Spreitzer, G. M. (2005). Empowerment at work. Working Paper Series, Michigan Ross School of Business.

Sürgevil, O., Tolay, E., \& Topoyan, M. (2013). Yapısal güçlendirme ve psikolojik güçlendirme ölçeklerinin geçerlilik ve güvenilirlik analizleri. Journal of Yaşar University, 8(31), 5371-5391. 
Tak, B., \& Aydemir, B. A. (2004). Örgütsel özdeşleşme üzerine iki görgül çalışma. 12.Ulusal Yönetim ve Organizasyon Kongresi Bildiri Kitabı (ss. 59-63).

Taştan, B. S. (2014). Örgüt iklimi ile örgütsel adanmışlık arasındaki ilişkide psikolojik güçlendirme algısının ara değişken olarak incelenmesi ve psikososyal kaynakların rolü: Kamu kesim çalışanları üzerine bir araştırma. Organizasyon ve Yönetim Bilimleri Dergisi, 6(1), 91-106.

Terzi, Y. (2019). SPSS ile istatistiksel veri https://avys.omu.edu.tr/storage/app/public/yukselt/108853/\%C4\%BOPP4.pdf (Erişim Tarihi: 6 Ocak 2020).

Thomas, K. W., \& Velthouse, B. A. (1990). Cognitive elements of empowerment: An interpretive model of intrinsic task motivation. Academy of Management Review, 15, 666-681.

Yanık, A., \& Açar, V. (2020). Sağlık çalışanlarında psikolojik güçlendirme algısının sinerjik iklim algısına etkisi. Mehmet Akif Ersoy Üniversitesi Sosyal Bilimler Enstitüsü Dergisi, 31, 61-75.

Zhu, W., Sosik, J. J., Riggio, E. R., \& Yang, B. (2012). Relationships between transformational and active transactional leadership and followers' organizational identification: The role of psychological empowerment. Leadership and Organizational Identification, 13(3), 186-212. 
This Page Intentionally Left Blank 